\title{
THE EFFECT OF FINANCIAL INCENTIVES ON TASK ATTRACTIVENESS AND INDIVIDUAL PERFORMANCE
}

\author{
Ascaryan Rafinda ${ }^{1,2 *}$, Timea Gal ${ }^{3}$, Ascariena Rafinda ${ }^{4}$, Putri Purwaningtyas ${ }^{5}$ \\ ${ }^{1}$ University of Debrecen, Károly Ihrig Doctoral School of Management and Business, Hungary \\ ${ }^{2}$ Faculty of Economics and Business Universitas Jenderal Soedirman, Indonesia \\ ${ }^{3}$ University of Debrecen, Faculty of Economics and Business Institute of Marketing and \\ Commerce, Hungary \\ ${ }^{4}$ Universitas Negeri Semarang, Faculty of Economics, Semarang, Indonesia \\ ${ }^{5}$ University of Debrecen, Faculty of Economics and Business Institute of Rural Development and \\ Engineering, Hungary
}

"Email corresponding author: ascaryan.rafinda@yahoo.com
Received 30/11/2020 Revised 22/01/2021 Published 31/01/2021

\begin{abstract}
The purpose of this paper is to examine the effect of financial incentives on unattractive task. Pre-test and post-test were conducted to examine the effect of financial incentives on unattractive task. The data generated from University Student in Indonesia. Total 53 participant follow two stages of the experiment to do the assignment. The first stage to examine individual performance in the assignment without incentives and the second stage is the treatment group. One group with financial incentives while another group without financial incentives. The T-Test was examining to evaluate the difference between pre-test and post test result. The result shows that financial incentives could not change people perceived of unattractive task become attractive and could not increase individual performance in unattractive task. But people that perceived the assignment as attractive, they improve the performance when there are financial incentives. This research found that money could not shift people perception on task attractiveness
\end{abstract}

Key Words: Financial Incentives, Task Attractiveness, Individual Performance.

\section{INTRODUCTION}

Financial incentive is the extrinsic motivator that based on individual performance. Even financial incentives have both effect increasing motivation to perform, its belief also encourage professional misconduct (Tayan, 2019). But Incentives are the easiest tools for motivating and improving individual performance (Atkinson et al., 2001). Compensation is linked to individual, groups or organizational performance which will be given to employees for performance that exceeds the expectations (Mathis and Jackson, 2002: 165). Theoretically, incentive schemes used to motivate individuals to generate more effort, which increased individual performance (Bonner et al., 2000). Baker et al. (1998) stated that the compensation based on incentive is typically used to align the interests of employees and the employer. Incentives rewards are the attraction to satisfy the needs in which every individual cannot obtain it without being a member of the organization (Anthony and Govindarajan, 2003: 135). The critical role of management accounting in compensation practices is to provide information that is useful in evaluating individual performance and motivate individuals to improve their performance (Bonner et al., 2000).

According to Bonner and Sprinkle (2002) the effectiveness of financial incentive in improving the performance of individuals affected by various factors such as the person variables (knowledge and skills), task variables (task complexity and task attractiveness), and environment variables (assigned goals). What factors make a financial incentive produce different results on individual performance, [see research Fessler (2003); Ariely et al. (2005); Drake et al. (2007); as well as Bailey and Fessler (2011)]. The relationship between financial incentives and individual performance is 


\section{PERFORMANCE}

Jurnal Personalia, Financial, Operasional,

Marketing dau Sistem Informasi

Performance. Volume 28 Nomor 1 Tahun 2021, 54-62

influenced by various factors (Jenkins et al., 1998). This study will discuss one of these factors, that is the task attractiveness (appeal assignment). Task attractiveness is the perception of how much a person enjoys the job or task assigned to him (Schpoont, 1955). Task attractiveness cause intrinsic motivation. Intrinsic motivation is found in the relationship between people and the task to be done, where the task at hand is considered attractive and raises satisfaction for his involvement with the task (Ryan and Deci, 2000).

According to Judge et al., (2001) and Fessler (2003) there is a positive correlation between task attractiveness and task performance. Fessler (2003) found that when the task is deemed attractive, incentive compensation will reduce task performance. Fessler (2003) shows that incentive compensation under certain conditions interacts and adversely affect task attractiveness and task performance. These results were confirmed by a study Bailey and Fessler (2011), which re-investigated the relationship of financial incentives with task attractiveness and task complexity with task performance. The results of this study show that financial incentives more effective in improving performance under conditions less complicated and less attractive compared with the attractive task and complex task. The results show that financial incentives more effectively improve individual performance in conditions unattractive task compared with the attractive task.

Differences conditions on the task attractiveness give influence on financial incentives that produce different performance results. When referring to research by Camerer and Hogarth (1999) contained the term "when incentive help" and "when incentive hurt". If we see the results from Fessler (2003) and Bailey and Fessler (2011) that "when incentives help" occurs in conditions unattractive task while "when incentive hurt" occurs in conditions attractive task.

Economists assume that the subjects of the experiment did not work freely and work harder, more persistent, and more effectively when they get many incentives for better performance. In terms of psychological believe that intrinsic motivation is good enough to make the business even without the presence of incentive compensation, and when more money or incentives will encourage more effort, but the effort does not always improve performance (Camerer and Hogarth, 1999). To test the truth of this study will re-examine the effect of financial incentives and task attractiveness on individual performance. This study will combine these two things and see how they affect before and after there is an incentive to the unattractive task and attractive task to individual performance through the experimental method. As previous study examines separately to find out the effect of financial incentives on task performance. This research examines the effect of financial incentives on unattractive assignment compare to attractive assignment. Based on the background, the problem in this study is whether financial incentives have a more significant effect on individual performance on unattractive task condition compared with attractive task condition? This study examine the Fessler term incentives helps in unattractive assignment.

\section{LITERATURE REVIEW AND HYPOTHESIS DEVELOPMENT}

There are two theories used in this study. Both of these theories are contradictory. First, expectancy theory which supports that financial incentives to improve performance. Second, motivation crowding theory that supports that financial incentives can degrade performance. Victor Vroom first proposed the expectancy theory. Expectancy theory shows that the strength of a tendency to act in a certain way depending on the strength of an expectation that this will be followed by the existing results and the attractiveness of that outcome to the individual (Robbins and Judge, 2009). Expectancy theory is a theory of motivation which people believe in the existence of a relationship between the effort that did work, the performance they have achieved from these efforts, and remuneration for effort and their performance (Lunenburg, 2011). The expectancy create motivation to people to do something as they have intrinsic motivation (Farrell, Grenier, and Leiby 2017). 
Performance. Volume 28 Nomor 1 Tahun 2021, 54-62

Expectancy theory consists of four assumptions. The first assumption is that people join the organisation with their expectations about their needs, motivations, and past experiences. The second assumption is that individual behaviour is the result of a conscious decision. That is, each is free to choose to behave by the calculation of their expectations. The third assumption that every individual wanted different things from an organisation such as a good salary and employment security. The fourth assumption that individuals will choose from a variety of alternatives to optimise their income (Lunenburg, 2011).

Frey and Jegen (2001) describe the motivation crowding theory is an external intervention through financial incentives, or penalties can be devastating, and under different conditions identified strengthening intrinsic motivation. The theory of intrinsic motivation of social psychological, both of them have connected in economic theory. Based on research by Frey and Jegen (2001) this case stems from a Nobel Solow (1971) and Arrow (1972) found that the condition of giving incentives to donors of blood does not raise blood supply exists. They are confused and can not detect the reason why the increase of financial incentives do not add to the blood supply. This theory is often called crowding out effect, which is the most critical anomalies in the economy, which this theory shows just the opposite of the fundamental economic law, which states a financial incentive to increase the supply. In crowding out effect show that financial incentives can reduce supply (Frey and Jegen, 2001). Even some researcher found that the larger the financial incentives could lead to dishonest behaviour (Gerlach, Teodorescu and Hertwig, 2019), but it's still the most common incentives that used in mostly organizations.

Expectations theory says that the employees will be motivated to issue a high level of effort when they are confident that these efforts will result in good performance. A proper assessment will generate organisational rewards such as bonuses, increases in employee benefits, or promotions. These awards will satisfy the personal goals of employees (Robbins and Judge, 2009). Conditions unattractive task make individual motivation is low. Unattractive task also perceived as difficult task. The difficult task could demoralize for individual as they perceived is as unachievable assignment (Locke and Latham, 2019). It makes people feel bored and not interested in the job so that it can lead to low performance. With the intervention of financial incentives, people will be motivated to work to improve performance. Previous research found that people with boring and repeated assignment have higher performance when there is pay per performance incentives (Benndorf, Rau and Solch 2019). The individual sees as expectations of financial incentives, where their efforts in working unattractive task would be appreciated.

On the other hand, the attractive conditions task to make people have high self-interest in the work he does. This makes the individual has high performance even without the intervention of a financial incentive. Psychological believe that intrinsic motivation is good enough to make the business even without the presence of incentive compensation, and when more money or incentives encourage more effort, but the effort does not always improve performance (Camerer and Hogarth, 1999).

The financial incentive has two kinds of influences: the standard direct price effect, which makes incentive is an attractive and indirect psychological influence. In some cases, the psychological effects of working in the opposite direction to the price effect and could crowd out incentive behaviour (Gneezy et al., 2011). If that happens the opposite direction between financial incentives and intrinsic motivation in this case self-interest at the attractive task it can cause a decrease in performance. On the other hand, Fessler (2003) and Bailey and Fessler (2011) proves that financial incentives more effectively improve performance when conditions are unattractive task compared to the attractive task. Based on the above, the proposed hypothesis of the study as follows:

$\mathrm{H}_{1}$ : Financial incentives have a more significant effect on individual performance when participant perceived as unattractive task compared with participant who perceived as attractive task. 


\section{RESEARCH METHODOLOGY}

This research generates the data using experimental. Financial incentives and task attractiveness are the independent variables. Financial incentives manipulated into two categories that are with financial incentive group and without financial incentives while task attractiveness manipulated into an attractive task and unattractive task. The dependent variable in this study is the individual's performance. The data collection takes total 1 months in December 2019. The student participates as volunteer to join the experiment. The location of this research is in the Faculty of Economics and Business, Universitas Jenderal Soedirman. Determining the location of this experiment is based on research that uses students as participants. The reason researchers use students from the faculty of economics and business because they are considered to understand the conditions of the business environment better. Many of those who will occupy positions in corporate management in the future. Psychology literature shows that decisionmakers in the real world have a pattern and characteristics of the processing of information with students (Nahartyo, 2013).

The research instrument used in this study refer from Kusufi (2012) which was a result of the adoption of Fessler (2003) which has been translated and developed by Arniati (2006) in the form of a water jar problem. Total of 15 questions on this experiment. The total of 15 questions divided into three sections so that each part consists of 5 questions. The first part, consisting of three pitchers of water with a weight value of 2 points per question. The second part consists of four pitchers of water with a weight value of 3 points per question. The third section composed of 5 pitchers of water with a weight value per about 5 points. Total maximum points that can be obtained by the participants was 50 points.

The stages of this experiment start with give all participant the same instrument and ask them whether it's interesting or not for them. The level of their interest on the assignment used as the basic classification as attractive or unattractive assignment. Then we decide to separate the group which perceived it as attractive assignment and other as unattractive assignment.

Table 1. Experiment Stage

\begin{tabular}{|c|c|c|}
\hline Pre-Test & & Post-Test \\
\hline \multirow{2}{*}{$\begin{array}{l}\text { All Participant } \\
\text { fill the } \\
\text { instrument } \\
(n=54)\end{array}$} & $\begin{array}{l}\text { Perceived as Attractive } \\
\text { assignment }(n=36)\end{array}$ & $\begin{array}{l}\text { Attractive group separate into two classes: } \\
\{\text { incentives }(n=18) \text { and non-incentives }(n=18)\}\end{array}$ \\
\hline & $\begin{array}{l}\text { Perceived as } \\
\text { unattractive assignment } \\
(n=16)\end{array}$ & $\begin{array}{l}\text { Unattractive group separate into two classes: } \\
\text { \{incentives }(\mathrm{n}=8) \text { and non-incentives }(\mathrm{n}=8)\}\end{array}$ \\
\hline
\end{tabular}

Source: author own calculation

\section{Experimental Procedure}

Based on the experimental design, there are four cell or groups. However, later, as the experiment progresses participants divided into two groups at random manipulated the group that there are a financial incentive and groups that no financial incentive. To determine the attractiveness task group, both groups will be analysed using task attractiveness questionnaires. Experimental procedures in this study as follows: 
Performance. Volume 28 Nomor 1 Tahun 2021, 54-62

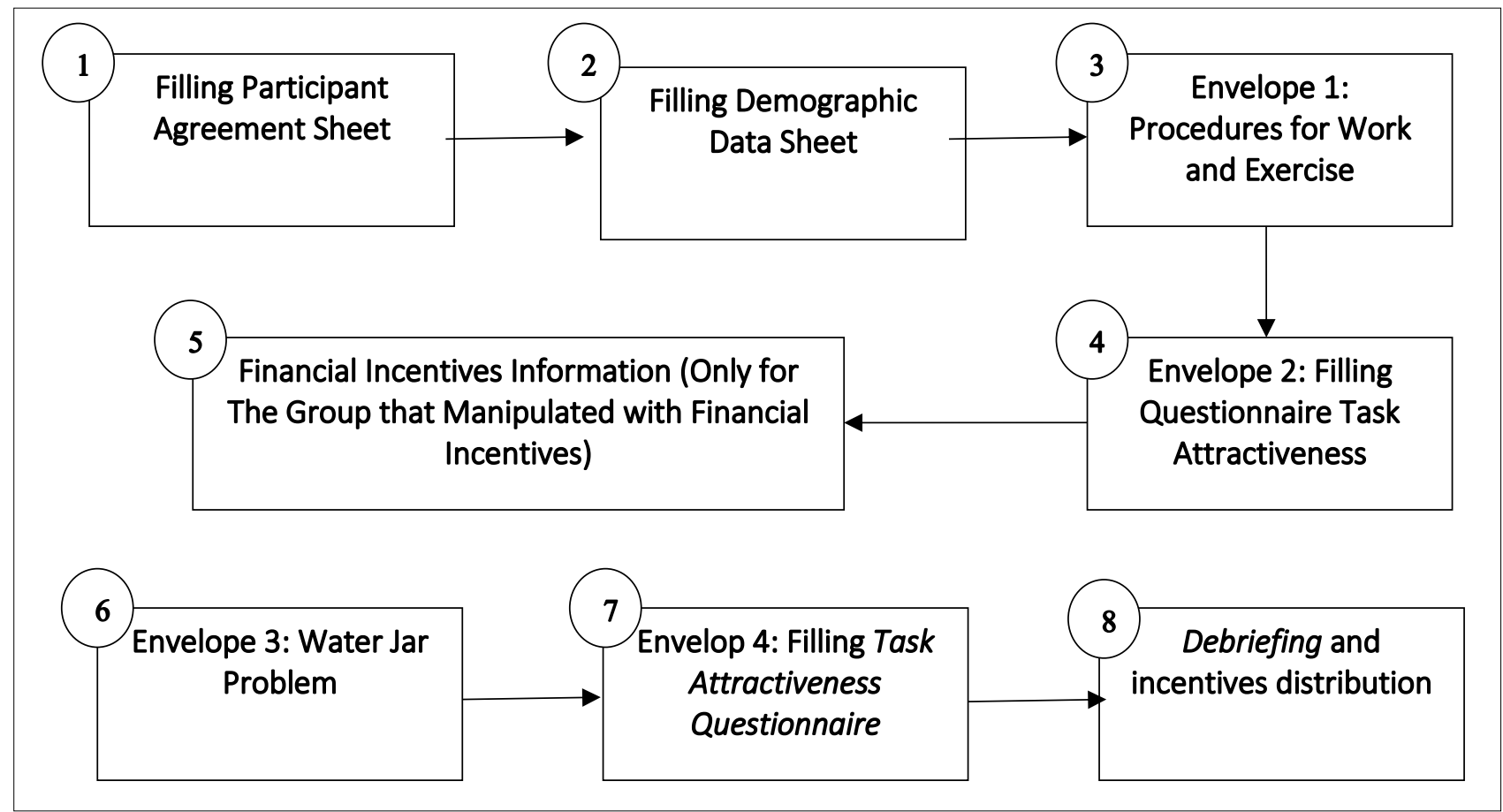

Figure 1. Experimental Procedure

Source: author own constructions

\section{Variable Operational Definition and Measurement}

The financial incentive in this study manipulated into 2 is with financial incentive and no financial incentive. For the group receiving financial incentives, incentive schemes used are incentive schemes piece-rates. Each point they get, they will get incentives 1.000 IDR for each point they get. In total there are 15 questions that have different weights. The first 5 questions have 10 points, 5 second questions have 15 points, and 5 third questions have 15 points.

For task attractiveness, participants were asked to measure their interest after work. These measurements using instruments belonging Fessler (2003) which consists of seven items that attractive - repulsive, exciting - dull, good - bad, interesting - boring, superior-inferior, wholesome - unwholesome, fun - tedious with a measurement scale 1-7. The measurement used is based upon research belongs Fessler (2003) which uses a cut-off 4.8 as a benchmark to determine the participants who are interested and less interested in the task. The dependent variable in this study is the individual performance. Performance measurement in this study using total points collected by each participant in the experiment work on the assignment.

\section{RESULT AND DISCUSSION}

Experiments have been conducted involving 53 students who are willing to be participants voluntarily. One participant failed due to not passed the manipulation checks. Thus, the final data which can be used in this research is 52 participants. Grouping into attractive and unattractive is depend on participant answer on the instrument. Fessler (2003) using a cut of score 4.8 to determine the participants who are interested and less interested in the task. At the end of the study, 52 participants divide into four cells.

Kolmogorov-Smirnov was used to check the normality. The result shows significant asymptotic value of $0.827>$ alpha $(\alpha=0.05)$ then it means the data normally distributed. This shows that the dependent variable is normally distributed within each category variable independent. Homogeneity test data using Levene's test of homogeneity of variance. The result shows the score is $0.125>$ alpha $(\alpha=0.05)$. Thus, it can be declared null hypothesis cannot be 
Jurnal Personalia, Financial, Operasional,

Marketing dau Sistem Informasi

Performance. Volume 28 Nomor 1 Tahun 2021, 54-62 rejected, or this data have the same variant in each category of the independent variable, in this case, meet the assumptions of T-Test. Descriptive statistical research can be seen in Table 2. Table 2 presents the average values (mean) of individual performance to variable financial incentives and task attractiveness and the standard deviation of each cell research. The details of the result:

Table 2. Statistical Descriptive

\begin{tabular}{|c|c|c|c|c|c|}
\hline \multirow{2}{*}{\multicolumn{2}{|c|}{$\begin{array}{l}\text { Pre-Test } \\
\text { Second Stage } \\
\text { No } \\
\text { Incentives } \\
\text { for all group } \\
\text { (1 class) } \\
\end{array}$}} & \multicolumn{2}{|c|}{ Post-Test } & \multirow{2}{*}{\multicolumn{2}{|c|}{ The difference }} \\
\hline & & Third Stage & $\begin{array}{l}\text { Fourth Stage } \\
\text { with treatment } \\
\text { ( } 4 \text { classes) }\end{array}$ & & \\
\hline \multirow{6}{*}{$\begin{array}{l}\text { All } \\
\text { Participant } \\
\text { fill the } \\
\text { instrument } \\
(n=53)\end{array}$} & \multirow{3}{*}{$\begin{array}{l}\text { Perceived as } \\
\text { Attractive } \\
\text { assignment } \\
(n=36) \\
\text { Mean: } 11,134 \\
\text { S.D: } 6,306\end{array}$} & \multirow{3}{*}{$\begin{array}{l}\text { Attractive } \\
\text { group separate } \\
\text { into two } \\
\text { classes: } \\
\text { \{incentives } \\
\text { (n=18) and non- } \\
\text { incentives } \\
(n=18)\}\end{array}$} & \multirow{3}{*}{$\begin{array}{l}\text { Incentives and } \\
\text { Attractive } \\
\text { Mean }=13,315 \\
\text { S.D }=5,218 \\
\text { Non-Incentives } \\
\text { and Attractive } \\
\text { (control) } \\
\text { Mean }=11,647 \\
\text { S.D }=4,689\end{array}$} & \multicolumn{2}{|c|}{$\begin{array}{l}\text { Attractive Group } \\
\text { ference: }\end{array}$} \\
\hline & & & & \begin{tabular}{|l|} 
Pre-Test \\
Mean:11,134 \\
S.D: 6,306 \\
N: 36 \\
\end{tabular} & $\begin{array}{l}\text { Post-Test } \\
\text { Mean:13,315 } \\
\text { S.D: } 5,218 \\
\text { N:18 }\end{array}$ \\
\hline & & & & \multicolumn{2}{|c|}{$13,315-11,134=2,181$} \\
\hline & \multirow{3}{*}{$\begin{array}{l}\text { Perceived as } \\
\text { unattractive } \\
\text { assignment } \\
\text { ( } n=16) \\
\text { Mean: } 10,421 \\
\text { S.D: } 4,720\end{array}$} & \multirow{3}{*}{$\begin{array}{l}\text { Unattractive } \\
\text { group separate } \\
\text { into two } \\
\text { classes: } \\
\text { incentives } \\
\text { (n=8) and non- } \\
\text { incentives }(n=8)\}\end{array}$} & \multirow{3}{*}{$\begin{array}{l}\text { Incentives and } \\
\text { Unattractive } \\
\text { Mean }=10,250 \\
\text { S.D }=7,573 \\
\text { Non-Incentives } \\
\text { and } \\
\text { Unattractive } \\
\text { (control) } \\
\text { Mean }=10,250 \\
\text { S.D }=4,131\end{array}$} & \multicolumn{2}{|c|}{$\begin{array}{l}\text { Unattractive Group } \\
\text { The difference: }\end{array}$} \\
\hline & & & & $\begin{array}{l}\text { Pre-Test } \\
\text { Mean:10,421 } \\
\text { S.D: } 4,720 \\
\text { N: } 16\end{array}$ & $\begin{array}{l}\text { Post-Test } \\
\text { Mean:10,250 } \\
\text { S.D: } 5,893 \\
\quad \mathrm{~N}: 8\end{array}$ \\
\hline & & & & \multicolumn{2}{|c|}{$10,250-10,421=-171$} \\
\hline
\end{tabular}

Source: authors own calculation

The different T-Test analyse conducted to examine the difference between the pre-test and posttest on both groups. The details of the result describe below:

Table 3. Difference T-Test Result

\begin{tabular}{|c|c|c|c|}
\hline Type of Group & $\begin{array}{c}\text { Pre-Test } \\
\text { (before treatment) } \\
\text { No incentives }\end{array}$ & $\begin{array}{c}\text { Post-Test } \\
\text { (after treatment) }\end{array}$ & Statistical Test \\
\hline \multirow{4}{*}{ Attractive Group } & & With Incentives & One Tail \\
\hline & & Mean: 13,315 & p-value 0,014 (sig) \\
\hline & Mean: 11,134 & S.D: 5,218 & \\
\hline & S.D: 6,306 & $\mathrm{~N}: 18$ & \\
\hline \multirow{4}{*}{ Attractive Control Group } & $N: 36$ & Without Incentives & One Tail \\
\hline & & Mean: 11,647 & p-value 0,476 \\
\hline & & S.D: 4,689 & (no sig) \\
\hline & & $\mathrm{N}: 18$ & \\
\hline \multirow{4}{*}{ Unattractive Group } & & With Incentives & One Tail \\
\hline & & Mean: 10,250 & p-value 0,387 \\
\hline & Mean:10,421 & S.D: 5,893 & (no sig) \\
\hline & S.D: 4,720 & $N: 8$ & \\
\hline \multirow{3}{*}{ Unattractive Control Group } & $\mathrm{N}: 16$ & Without Incentives & One Tail \\
\hline & & S.D: 4,131 & (no sig) \\
\hline & & $N: 8$ & \\
\hline
\end{tabular}

Source: authors own calculation 
Performance. Volume 28 Nomor 1 Tahun 2021, 54-62

The statistical test result on table 3 shows that participant on unattractive group were not influence by the incentives scheme, on the other hand the attractive group influence by the incentives scheme. Based on the analysis above, the research hypothesis is not supported or rejected. The hypothesis states that financial incentives have a more significant effect on individual performance when unattractive task compared with the attractive task. Results of the analysis showed the opposite of the hypotheses. Incentives has more effect on attractive group performance than on unattractive group performance. This research found that the hypotheses rejected, it implies that this research find opposite direction than the Fessler (2003) and Bailey and Fessler (2011) statement that financial incentives could improve performance.

The research hypothesis is rejected can be caused by various things. Most notable is the difference in the number of participants who were in a group of an attractive and unattractive group. Differences in the number of participants cannot be controlled by researchers due to the perception of interest in pure duty is determined by each participant. Each participant has their perception of the tasks performed experiments.

Many participants who choose the task of the experiment as an attractive task can cause some assumptions. The first assumption in terms of instrument tool used water jar problem. The instrument water jar problem already has its charm. The uniqueness about which participants are required to use logic calculations work on the problems is an attractive thing for participants. Assuming both seen from the characteristics of participants who followed the experiment. Most of them have never participated in research experiments, and experimental research activities are rarely done. Thus, participants assume the experiment is something interesting. In the end, participants who followed the experimental feel enthusiastic and eager to take part in this experiment. Another thing that is surprising from this study is that the average level of performance similar between the group has given incentives and groups without incentives in conditions unattractive. Injections of manipulation in the form of incentives does not seem to have a significant impact on the performance of individuals.

\section{CONCLUSION}

Based on the results of research that has been conducted shows that the hypothesis of financial incentives has a more significant effect on the performance of individual on unattractive task conditions compared with attractive task condition is rejected. This research finding is one of the proofs that Camerer and Hogarth (1999) statement that "when incentive help" and "when incentive hurt" is not proven in this research. Referring to the findings raised a variety of issues, assumptions, and new questions over the rejection of the hypothesis. Such as, the problem of balancing the number of participants is based on the perception of interest in the task. Individual's perception of interest in the task cannot be controlled by the researcher. It also depends on the type of instrument or tool used. If the tool already has a unique instrument, participants tend to assume that the interesting instrument tool. However, if the instrument requires participants a task that is considered normal as a matter of accounting, participants might be less likely to feel uninterested. The possibility of using different kinds of instruments to measure interest in the task can produce different findings. This needs to be investigated through further research.

The other thing is the assumption that the participants feel enthusiastic with the experimental activity that is rarely done in the participants. Enthusiasm could interfere with studies where participants are eager to follow the experiment. The experiment is regarded as a new experience for them. A new experience is regarded as something interesting to raise the enthusiasm regardless of manipulation given. It is interesting to study where enthusiasm for the experiment can interfere with the results of the experiment. Subsequent studies, the researchers will investigate the perception of interest in the task (instrument) and the enthusiasm of the participants in following the experimental activities in more depth. The conclusion of this study is variable financial incentives has an effect on individual performance under attractive assignment 


\section{PERFORMANCE}

Jurnal Personalia, Financial, Operasional,

Marketing dau Sistem Informasi

Performance. Volume 28 Nomor 1 Tahun 2021, 54-62

and has no effect on unattractive assignment. Participant not change their perceived of the assignment and also not change their performance even the money incentives exist.

Further implication for Indonesian researcher, should be more careful on task attractiveness experiment. Indonesian society not to common with experiment. This could have perceived the assignment on experiment as attractive. Then the distribution of attractiveness could not be equal. This research also found that people perceived on assignment could not change even with money incentives. They keep believe the assignment as unattractive even there is money as incentives.

\section{REFERENCE}

Anthony, Robert N., dan Vijay Govindarajan. (2003). Sistem Pengendalian Manajemen. Salemba Empat. Jakarta.

Ariely, Dan, Ury Gneezy, George Loewenstein, dan Nina Mazar. (2005). Large Stakes and Big Mistakes. Working Papers Federal Reserve Bank of Boston No.05-11.

Arniati. (2006). Pengaruh Insentif Keuangan, Daya Tarik Tugas, dan Faktor Situasional pada Kinerja. Tesis. Program MSi dan Doktor FEB UGM, Yogyakarta.

Atkinson, A. A., Banker, R., Kaplan, R. S., a Young, S. M. (2001). Management Accounting (3rd edition). Upper Saddle River, NJ: Prentice-Hall.

Bailey, Charles D. dan Nicholas J. Fessler. (2011). The Moderating Effect of Task Complexity and Task Attractiveness on the Impact of Financial Incentives in Repeated Task. Journal of Management Accounting Research 23: 189-210.

Benndorf, V., Rau, H.A and Solch, C., (2019). Gender differences in motivational crowding out of work performance. Econ. Inq. 57 (1), 206-226.

Bonner, S. E., Reid Hastie, Geoffrey B. Sprinkle, \& S. Mark Young. (2000). A Review of The Effects of Financial Incentives On Performance In Laboratory Task: Implications for Management Accounting. Journal of Management Accounting Research 12: 19-64.

and G. B. Sprinkle. (2002). The Effect of Financial Incentives on Effort and Task Performance: Theories, Evidence, and A Framework for Research. Accounting, Organization and Society 27: 303-345.

Camerer, Colin F. dan Robin M. Hogarth. (1999). The Effects of Financial Incentives in Experiments: A Review and Capital-Labor-Production Framework. Journal of Risk and Uncertainty 19: 1-3;7-42.

Farrell, A. M., J. H. Grenier, and J. Leiby. (2017). Scoundrels or stars? Theory and evidence on the quality of workers in online labor markets. The Accounting Review 92 (1): 93-114

Fessler, Nicholas J. (2003). Experimental Evidence on the Links Among Financial Incentives, Task Attractiveness, and Task Performance. Journal of Management Accounting Research 15: 161-176.

Frey, Bruno S. dan Reto Jegen. (2001). Motivation Crowding Theory. Journal of Economic Surveys Vol.15 No.5: 589-611. 
Gneezy, Ury, Stephan Meier, dan Pedro Rey-Biel. (2011). When and Why Incentives (Don't) Work to Modify Behavior. Journal of Economic Perspectives Vol.25 No.4: 191-210.

Gerlach, P., Teodorescu, K., and Hertwig, R. (2019). The truth about lies: A meta-analysis on dishonest behavior. Psychological Bulletin, 145(1), 1-44. https://doi.org/10.1037/bul0000174

Hartono, Jogiyanto. (2013). Metodologi Penelitian Bisnis Salah Kaprah dan PengalamanPengalaman. BPFE. Yogyakarta.

Jenkins, G. Douglas, Atul Mitra, Nina Gupta, dan Jason D. Shaw. (1998). Are Financial Incentives Related to Performance? A Meta-Analytic Review of Empirical Research. Journal of Applied Psychology 83: 777-787.

Judge. Timothy A, Carl J. Thoresen, Joyce E. Bono, and Gregory K. Patton. (2001). The Job Satisfaction-Job Performance Relationship: A Qualitative and Quantitative Review. Psychological Bulletin 127 No.3: 376-407.

Kartikawati, Lisa. (2015). Pengaruh Budget Based Incentive Contracts dan Budget Level dalam Kinerja Individu. Skripsi. Universitas Jenderal Soedirman, Purwokerto.

Kusufi, Muhammad Syam. (2012). Hubungan Insentif Keuangan Terhadap Daya Tarik Tugas, Usaha, dan Kinerja: Studi Eksperimen. Tesis. Universitas Gadjah Mada.

Locke, E. A., and Latham, G. P. (2019). The development of goal setting theory: A half century retrospective. Motivation Science, 5(2), 93-105. https://doi.org/10.1037/mot0000127

Lunenburg, Fred C. (2011). Expectancy Theory of Motivation: Motivating by Altering Expectations. International Journal of Management, Business, and Administrations. Volume 15 No.1.

Mathis, Robert L., dan John H. Jakson. (2002). Human Resources Management. Salemba Empat. Jakarta.

Nahartyo, Ertambang. (2013). Desain dan Implementasi Riset Eksperimen. UPP STIM YKPN. Yogyakarta.

Puspita, Lisa Martiah Nila. (2014). Motivasi, Insentif Moneter dan Kinerja: Sebuah Eksperimen. Jurnal Simposium Nasional Akuntansi 17 Mataram. Universitas Bengkulu.

Robbins, Stephen P. dan Timothy A. Judge. (2009). Perilaku Organisasi. Salemba Empat. Jakarta.

Ryan, Richard M. and Edwar L. Deci. (2000). Intrinsic and Extrinsic Motivations: Classic Definitions and New Directions. Contemporary Educational Psychology 25: 54-67.

Schpoont, Seymour Hirsh. (1955). Some Relationship Between Task Attractiveness, Self Evaluated, Motivation, and Success or Failure. Tesis. The University of Illinois.

Tayan, B. (2019). The Wells Fargo cross-selling scandal. Stanford Closer Look Series. 